\title{
Proprotein-processing Endoprotease Furin Controls the Growth and Differentiation of Gastric Surface Mucous Cells
}

\author{
Yoshitaka Konda, ${ }^{\star}$ Hiromi Yokota, ${ }^{*}$ Tsuyoshi Kayo, ${ }^{\star}$ Tadashi Horiuchi, ${ }^{\ddagger}$ Norifumi Sugiyama,, Shigeyasu Tanaka, $\$$ \\ Kuniaki Takata, ${ }^{\S}$ and Toshiyuki Takeuchi* \\ *Department of Molecular Medicine, and ${ }^{\S}$ Department of Cell Biology, the Institute for Molecular and Cellular Regulation, Gunma \\ University, Maebashi 371, Japan; and ${ }^{\ddagger}$ Molecular Research Laboratory, Daiichi Pharmaceutical Co., Ltd., Tokyo 134, Japan
}

\begin{abstract}
Gastric surface mucous cells originate from progenitor cells at the isthmus of the gastric gland, from where the cells migrate to the luminal surface. With migration they form secretory granules and express TGF $\alpha$. We found that proprotein-processing endoprotease furin-positive cells were layered around the upper one fourth of the gastric glands of adult rats, whereas they were distributed along an outer epithelial layer in fetal rats. Because the furin-positive cell layer was localized from the upper cell proliferating zone to the less proliferating pit-cell region in the gastric gland unit, we examined the role of furin in the growth and differentiation of surface mucous cells by using the cell line, GSM06. This cell line is derived from the gastric surface mucous cells of transgenic mice harboring the temperature-sensitive simian virus $40 \mathrm{~T}$ antigen. At $\mathrm{T}$ antigen-active temperature $\left(33^{\circ} \mathrm{C}\right)$, the cells grew to confluency, whereas at $\mathrm{T}$ antigen-inactive temperature $\left(39^{\circ} \mathrm{C}\right)$, the cells ceased growing. At $33^{\circ} \mathrm{C}$, the cells exhibited a high level of furin expression with a negligible level of periodic acid Schiff (PAS)-positive materials and a low level of TGF $\alpha$. In contrast, at $39^{\circ} \mathrm{C}$ the cells produced a high level of PAS-positive materials, TGF $\alpha$, and secretory granules, with a negligible level of furin expression. To further examine the role of furin, we established a GSM06 cell line introduced with either a sense or an antisense furin cDNA. The cells with sense furin expression produced fewer PAS-positive materials and a low level of TGF $\alpha$ even at $39^{\circ} \mathrm{C}$, whereas the cells with antisense furin expression exhibited more PAS-positive materials and TGF $\alpha$ even at $33^{\circ} \mathrm{C}$. When furin expression was suppressed by its antisense oligonucleotide, the cell growth was retarded with enhanced expression of the differentiated characteristics. Thus, we conclude that furin is instrumental in controlling the growth of the surface mucous cells. (J. Clin. Invest. 1997. 99:18421851.) Key words: gastric surface mucous cells • furin • perodic acid Schiff-positive materials • transforming growth factor- $\alpha \cdot$ cell growth
\end{abstract}

Address correspondence to Toshiyuki Takeuchi, Department of Molecular Medicine, Institute for Molecular and Cellular Regulation, Gunma University, Showa-machi, Maebashi 371, Japan. Phone: 81272-20-8855; FAX: 81-272-20-8896; E-mail: tstake@news.sb.gunmau.ac.jp

Received for publication 4 September 1996 and accepted in revised form 11 February 1997.

J. Clin. Invest.

(C) The American Society for Clinical Investigation, Inc. 0021-9738/97/04/1842/10 \$2.00

Volume 99, Number 8, April 1997, 1842-1851

\section{Introduction}

Gastric surface mucous cells form a tubular structure by lining the wall of the gastric foveolar region (also called gastric pit) and the luminal surface region. The cells originate from the granule-free progenitor cells located at the isthmus of the gastric gland unit (1). From the isthmus they move upwards and develop to maturity through three stages: a pre-pit cell stage, a mature pit cell stage, and a final top pit cell stage with a turnover life of $\sim 3 \mathrm{~d}$ in mouse gastric glands (2). The maturation of the cells is well characterized by the appearance of secretory granules, which are initially absent in the progenitor cells (thus called granule-free cells). Secretory granules begin to appear at a pre-pit cell stage and increase in number as the cells develop to mature pit cells. The mature cells contain a number of circular secretory granules full of mucin-like materials (2). In addition to the morphological characteristics, the surface mucous cells exhibit specific biochemical characteristics with periodic acid Schiff (PAS) ${ }^{1}$ staining: synthesis and secretion of the two major components, macromolecular mucin and surfaceactive phospholipids $(3,4)$. With the morphological feature of secretory granules and the biochemical characteristic of PASpositive staining, the cells are distinct from other mucosal cell subtypes such as parietal cells and chief cells $(4,5)$.

From a granule-free to a top pit cell stage, the differentiation of the surface mucous cells is regulated in an orchestrated manner by a variety of growth and differentiation factors, and cellto-cell and/or cell-to-matrix interaction signals $(6,7)$. Such growth and differentiation factors may include epidermal growth factor $(7,8)$, TGF $\alpha(9,10)$, heparin-binding EGF-like growth factor (11), hepatocyte growth factor (12), insulin-like growth factor-1 (10), and gastrin (6). Among these factors, TGF $\alpha$ is known to be produced in surface mucous cells, and increases when the cells move up to the upper pit wall of the gastric gland $(13,14)$. TGF $\alpha$ is also produced in greater amounts in parietal and chief cells (14-16). TGF $\alpha$, EGF, and heparinbinding EGF-like growth factor share a common receptor that is highly expressed in parietal cells and moderately expressed in surface mucous cells, but not in a proliferating progenitor cell zone at the isthmus $(11,17)$. Recently, EGF/TGF $\alpha$ receptors were found to be localized to the basolateral region of luminal surface mucous cells (18). Because the surface mucous cells near the gastric lumen lose proliferative capacity, TGF $\alpha$ may act not only for cell growth but also for cell differentiation. Thus, TGF $\alpha$ as well as PAS-stained materials are expressed in mature gastric surface mucous cells.

1. Abbreviations used in this paper: BrdU, bromodeoxyuridine; PAS, periodic acid Schiff; PCNA, proliferating cell nuclear antigen; SV40, simian virus 40 . 
A primary culture of gastric surface epithelial cells has been well established by many investigators using the fundic mucosa from 1-2-wk-old rats (19), 25 gestational-d-old rabbits (20), adult dogs (10), and 16.5 gestational-d-old rats (21). These cultured cells exhibited a variety of characteristic features of surface mucous cells including TGF $\alpha$ responsiveness (10), production of PAS-positive materials $(19,20)$ and prostaglandins (20), and expression of cathepsin E (21). Although the primary culture method has many advantages over the cultured cell line method in gastric cell research, two major limitations of the primary cell culture method include an inability of cell passage and an inefficiency of gene transfer for expression studies. A cultured cell line accepts gene transfer more readily and is useful in cell differentiation studies, but highly differentiated functions tend to diminish with passage (22). To overcome this drawback of a cultured cell line, a novel method of establishing a culture cell line was devised using a temperature-sensitive simian virus 40 (SV40) large T antigen as a transforming gene $(23,24)$. A cultured cell line transformed with this temperature-sensitive $\mathrm{T}$ antigen is known to be useful in studying the differentiation process of cells (23-25). At the permissive temperature of $33^{\circ} \mathrm{C}$, the cells are able to grow as usual because the $\mathrm{T}$ antigen is active at this temperature. When placed at the nonpermissive temperature of $39^{\circ} \mathrm{C}$, which inactivates the $\mathrm{T}$ antigen, the cells cease growing and begin to exhibit their differentiated characteristics. The GSM06 cell line is derived from the gastric surface mucous cells of a transgenic mouse that was transformed with the temperature-sensitive SV40 T antigen DNA (25). Morphologically, GSM06 cells are rounded or polyhedral as is typical of primary cultured gastric surface mucous cells $(10,19-21)$. Electron microscopy revealed that the cells contained a small number of secretory granules (26). The PAS-positive staining of the GSM06 cells appeared to be due to glycoproteins and glycolipids, but not to mucin molecules (27). In a confluent state at $33^{\circ} \mathrm{C}$, or even in a nonconfluent state at $39^{\circ} \mathrm{C}$, the cells begin to produce PASpositive materials that form a mucous sheet as seen in the gastric surface mucous cells $(25,27)$.

Many growth-related proteins are generated as a precursor, and their activation may be regulated by cleavage enzymes. As we have demonstrated using the pancreatic $\beta$ cell line MIN6 (22), the proprotein processing enzyme, furin may be one of the enzymes involved in the regulation of cell growth and differentiation. Furin belongs to a member of the yeast Kex2-like family and converts many precursors to their bioactive forms at the trans-Golgi network (28). Cleavage by furin is specific for a unique amino acid sequence $\mathrm{Arg}^{-4}-\mathrm{X}-\mathrm{X}-\mathrm{Arg}^{-1}$. This motif is found in many growth-related peptides or proteins (29). In the gastric mucosa there are a number of such candidates: a procadherin family of adhesion molecules (30); matrix metalloproteinases such as meprin A, stromelysin-3, and membrane-type matrix metalloproteinases (31-33); several growth factor precursors including PDGF and TGF- $\beta(34,35)$, and some growth factor proreceptors such as the insulin receptor, IGF-1 receptor, and hepatocyte growth factor receptor (oncoprotein $M E T$ ) $(36,37)$. These furin-cleavable precursors may function for the growth and differentiation of gastric mucosal cells.

We investigated the role of furin in the growth and differentiation of surface mucous cells using the cell line GSM06. By changing the temperature and cell density of the culture, we measured the growth and differentiation of the surface mu- cous cells with three markers: PAS staining-positive materials, $\mathrm{TGF} \alpha$, and furin expression. The present study demonstrates that the expression of furin in the GSM06 cells produces an immature state of the surface mucous cells, whereas the suppression of furin expression induces their differentiated characteristics, even in a nonconfluent state at $33^{\circ} \mathrm{C}$.

\section{Methods}

Cell culture. As a culture model of the surface mucous cells, we used a GSM06 cell line. This cell line was established from the gastric surface mucous cells of transgenic mice harboring temperature-sensitive simian virus 40 large $\mathrm{T}$ antigen gene (25). The cells were cultured on a collagen type I-coated plastic plate (Iwaki, Tokyo, Japan) in Dulbecco's Modified Eagle's medium/Ham's F-12 medium (Sigma Chemical Co., St. Louis, MO) supplemented with 10\% FBS (Gibco Laboratories, Grand Island, NY), 1\% ITES (100\% ITES; insulin 2 mg/liter, transferrin $2 \mathrm{mg} /$ liter, ethanolamine $0.122 \mathrm{mg} / \mathrm{liter}$, sodium selenite $9.14 \mu \mathrm{g} /$ liter), and $10 \mathrm{ng} / \mathrm{ml} \mathrm{EGF}$ in a humidified $5 \% \mathrm{CO}_{2}$ atmosphere at $33^{\circ} \mathrm{C}$ unless otherwise indicated. The cells were grown at this temperature until a confluent monolayer was formed. Culture at $39^{\circ} \mathrm{C}$ started when the cells reached the cell density described below. The cells were cultured in high or low cell density. High density culture was defined as the condition in which the cells were confluent, low cell density was defined as $10 \%$ confluent.

Histologic studies. For examining the proliferation of the fetal or adult rat gastric mucosa, we used two methods, the thymidine analogue, bromodeoxyuridine (BrdU) incorporation method (38-40), and the staining of proliferating cell nuclear antigen (PCNA) (40). BrdU ( $80 \mathrm{mg} / \mathrm{kg}$ body wt; Sigma Chemical Co.) was injected intraperitoneally into pregnant Wistar rats at gestational day 18, or Wistar rats at neonatal day 35 (Japan SLC, Hamamatsu, Japan) $6 \mathrm{~h}$ before killing. Stomach tissues were removed from rats at gestational day 18 or at postnatal day 35. After mincing, the tissue was fixed in $4 \%$ paraformaldehyde in $0.1 \mathrm{M}$ phosphate buffer, $\mathrm{pH}$ 7.4. Small pieces of the sample were incubated consecutively with $10 \%$ and then $20 \%$ saccharose in $0.1 \mathrm{M}$ phosphate buffer, pH 7.4. After saccharose replacement, the samples were frozen, and then sectioned by a microtome. The sections were placed on a glass slide. The mouse antiBrdU monoclonal antibody (BioMeda, Foster City, CA) recognizes BrdU molecules in denatured single strand DNA; thus, before staining, the sections were partially denatured by the incubation in $95 \%$ formaldehyde in $0.15 \mathrm{M}$ trisodium citrate at $70^{\circ} \mathrm{C}$ for $45 \mathrm{~min}$. Then the sections were processed using an LSAB2 staining kit (DAKO Japan, Kyoto, Japan) according to the manufacturer's instruction.

Immunostaining of PCNA was performed on cryostat microtomesectioned tissues using a mouse monoclonal anti-PCNA antibody (PC10; DAKO SA, Glostrup, Denmark) and an LSAB2 staining kit (DAKO Japan) (40).

Immunostaining of furin was performed by a previously described method (39). Stomach tissue sections were prepared by the same procedure as used for the BrdU and PCNA stainings. GSM06 cells were cultured on a chamber slide (Nunc Inc., Naperville, IL). After fixation in $4 \%$ paraformaldehyde in $0.1 \mathrm{M}$ phosphate buffer, $\mathrm{pH} 7.4$, tissue sections or GSM06 cells were probed with rabbit antifurin serum (ST-73). They were then incubated with indodicarbocyanine (Cy3)conjugated affinity-purified donkey anti-rabbit IgG (Jackson ImmunoResearch Labs., Inc., West Grove, PA). The specimens were examined using a microscope with an incident illuminator (BX50; Olympus Corp., Lake Success, NY).

For PAS staining, stomach tissue sections or GSM06 cells on a chamber slide were fixed in $10 \%$ formaldehyde for $3 \mathrm{~h}$ at $4^{\circ} \mathrm{C}$ and stained with PAS using the standard method (41). Briefly, samples were oxidized for $15 \mathrm{~min}$ with $0.5 \%$ periodic acid. After washing, they were immersed for $15 \mathrm{~min}$ in Schiff's reagent, and then for $4 \mathrm{~min}$ two times in $1 \% \mathrm{NaHSO}_{3}$ and $0.1 \% \mathrm{HCl}$. After washing the samples with tap water, they were stained with hematoxylin. 
For examination via electron microscopy (EM), GSM06 cells were scraped from the plastic plate and packed in $4 \%$ agarose. The cells were then fixed in $\mathrm{OsO}_{4}$ and processed for EM.

Northern blot analysis. For isolation of the total RNA from GSM06 cells, the cells were cultured in a $10-$ or $15-\mathrm{cm}$ plastic plate, and rinsed with ice-cold $\mathrm{Ca}^{2+}-\mathrm{Mg}^{2+}-$ free $\mathrm{PBS}(-)$. Total RNA isolation was performed as previously described (22). The total RNA was electrophoresed on a $1.0 \%$ agarose gel and transferred to a nylon membrane (Amersham Japan, Tokyo, Japan). Hybridization was performed with a priming procedure as previously described (22). The membrane was exposed to an x-ray film (Eastman Kodak Co., Rochester, NY) with an intensifying screen at $-80^{\circ} \mathrm{C}$.

Immunoblotting for furin and $T G F \alpha$. For immunodetection of furin and TGF $\alpha$, GSM06 cells were cultured as described above. The cells were harvested with ice-cold $10 \%$ trichroloacetic acid and left for $1 \mathrm{~h}$ on ice. Cell precipitates were collected and centrifuged at $10,000 \mathrm{~g}$ for $10 \mathrm{~min}$ at $4^{\circ} \mathrm{C}$. After removing supernatant, cell pellets were lysed with $80 \mu \mathrm{l}$ of Urea TX solution ( $9 \mathrm{M}$ urea, $2 \%$ Triton X-100, $5 \%$ 2-mercaptoethanol), and then sonicated shortly. To the sonicated samples, $20 \mu \mathrm{l}$ of LDS solution (10\% lithium dodecylsulfate, $0.1 \%$ bromophenol blue) was added for cell lysate preparation. Cell lysates were sonicated again, and then adjusted to $\mathrm{pH} 7.4$ with $2 \mathrm{M}$ Tris- $\mathrm{HCl}$. Cell lysates were electrophoresed on a $20 \%$ polyacrylamide gel under a reducing condition. Separated proteins were blotted onto a nitrocellulose membrane and probed with rabbit antifurin antiserum (ST-73) or with anti-TGF $\alpha$ monoclonal anitibody (Santa Cruz Biotechnology, Santa Cruz, CA). Antibody-reacted bands were detected using an ECL detection system (Amersham International, Little Chalfont, UK).

Measurement of cell growth. We used a cell counting kit based on the action of WST-1 [2-(4-iodophenyl)-3-(4-nitrophenyl)-5-(2,4-disulfophenyl)-2H-tetrazolium, monosodium salt] (Dojindo Lab, Kumamoto, Japan), and the cell number was evaluated with the absorbance of optical density at $450 \mathrm{~nm}$ (42). Briefly, cells were cultured at $3 \times 10^{3}$ cells/well on a collagen I-coated 96-well plate. After removing the culture medium and washing with PBS, the cells were further incubated for $3 \mathrm{~h}$ in the assay solution with WST-1. Then OD $450 \mathrm{~nm}$ was measured with a spectrophotometer. For each experiment, an average of eight sample OD values were calculated and at least three experiments were performed for each assay point. The value obtained from the cell culture under a variety of $\mathrm{ZnCl}_{2}$ concentrations was expressed as a percentage of the control value without $\mathrm{ZnCl}_{2}$. Values with this method were linearly correlated with the corresponding cell numbers by counting with a hemocytometer $\left(r^{2}=0.995\right)$.

Establishment of sense and antisense furin cDNA-expressing GSM06 cells. To investigate the role of furin in the growth of GSM06 cells, we constructed the two furin expression vectors using pMEP4 (Invitrogen Corp., San Diego, CA), which carries a heavy metalinducible metallothionein promoter (22). One vector contained a sense strand of the full length furin cDNA, the other contained an antisense strand. The antisense furin cDNA was made by inserting the cDNA covering the first 364 amino acids of the mouse furin precursor sequence into the pMEP4 in a reverse direction (43). GSM06 cells were transformed with these vectors or with an empty pMEP4 by the lipofection method using DOTAP (Boehringer Mannheim, Indianapolis, IN). Transformed cells were selected to a single colony by maintaining the culture in a medium containing hygromycin B $(0.1 \mathrm{mg} / \mathrm{ml}$, Sigma Chemical Co.). To evaluate the effect of furin expression on the growth of GSM06 cells, $\mathrm{ZnCl}_{2}$ was added to the culture medium to activate the metallothionein promoter that controls the expression of sense or antisense furin cDNA. $\mathrm{ZnCl}_{2}$ alone, up to $100 \mu \mathrm{M}$, did not cause any change in cell viability, cell growth, PAS staining, or expression of TGF $\alpha$, as long as the cells were cultured in the medium containing $10 \%$ FBS. However, when $\mathrm{ZnCl}_{2}$ was added to the culture medium without FBS, the cells began to detach from the bottom of the plastic dish.

Measurement of cell growth with antisense furin oligonucleotidetreated conditioned medium. To determine the effect of furin expres- sion on the growth of GSM cells, we used an antisense oligonucleotide to suppress furin in addition to the above described experiment. Because we did not need to use $\mathrm{ZnCl}_{2}$ in this experiment, we were able to culture the cells in a serum-free medium. Antisense oligonucleotide (5'-CACCCATAGCAACCAGGATCTCAGCTCCAT-3') and sense oligonucleotide ( $5^{\prime}$-ATGGAGCTGAGATCCTG $\overline{\text { GTTGC- }}$ TATGGGTG-3') were designed to cover the start codon for furin cDNA (43). The oligonucleotides were synthesized using a nucleotide phosphorothioate method to prevent the degradation from nucleases (44). The antisense oligonucleotide was used to suppress furin expression, while the sense oligonucleotide was used as a control. For culturing GSM06 cells, we used serum-free medium PM-1000 (Eiken Chemical Co., Tokyo, Japan) with $0.1 \%$ BSA (Sigma Chemical Co.). The cells were cultured in the presence or absence of various concentrations of the sense or antisense oligonucleotide for $48 \mathrm{~h}$ before the cells were counted.

We investigated the effect of the conditioned medium prepared in the presence or absence of the sense or antisense oligonucleotide on the growth of the intact GSM06 cells. Briefly, the cells were cultured in 10-cm collagen-coated plates in a serum-free P-1000 medium with $0.6 \mu \mathrm{M}$ sense or antisense oligonucleotide for $24 \mathrm{~h}$. The medium was collected from each dish and concentrated to 1/100 vol using the Centricon 3 microconcentrator (Amicon Inc., Beverly, MA). To culture the intact GSM06 cells, concentrated conditioned medium was added to a fresh PM- 1000 medium consisting of $1 \%$ of the total volume. After culturing the cells for $24 \mathrm{~h}$, the cell number was measured with the WST-1 method. Each experiment was performed at least three times and the values were expressed as mean \pm SEM.

Data analysis. Comparisons between multiple groups were made using repeated-measures analysis of variance; when significant differences were found, further comparisons were made using the paired $t$ test. Differences were considered significant at $P<0.05$.

\section{Results}

Characteristics of gastric mucosal cells of fetal and adult rats. The gastric epithelium of fetal rats at gestational days 16 and 17 is covered mostly by a simple layer, and partly by a stratified layer of cuboidal cells $(21,45,46)$. Towards birth, gastric epithelium becomes a single layer of columnar cells and begins to invaginate and form a pit and glandular crypt structure. After birth, gastric epithelium develops into a complex gastric gland composed of several functionally distinct cell subtypes, until the weaning period (47). We compared the characteristics of gastric epithelial cells between gestational day 18 and postnatal day 35 using three markers: cell proliferating capacity by BrdU incorporation or by PCNA staining, formation of PASpositive materials, and expression of furin. The epithelium at gestational day 18 was made up of a stratified layer of roundto-oblong-shaped cells (Fig. $1 A$ ). Many nuclei in both mucosal and submucosal cells were stained dark brown by BrdU incorporation, while nonstained nuclei remained blue. In epithelium, the BrdU-positive cells were observed mostly along the basal epithelial layer, but a few in the upper epithelium. These findings indicate that there is extensive cell division at this stage. With PAS staining (Fig. $1 B$ ), the mucosal and submucosal cells, but not muscular cells, were lightly positive, indicating that the capacity to synthesize glycoconjugates is slightly developed at this stage. Furin immunostaining was strongly positive along an outer epithelial cell layer where a few BrdUpositive cells were scattered, but negative along the basal epithelial cell layer where BrdU-positive cells were enriched (Fig. $1 C$ ). There are some furin-positive cells scattering in a submucosal layer. Although the epithelial, subepithelial, and muscu- 

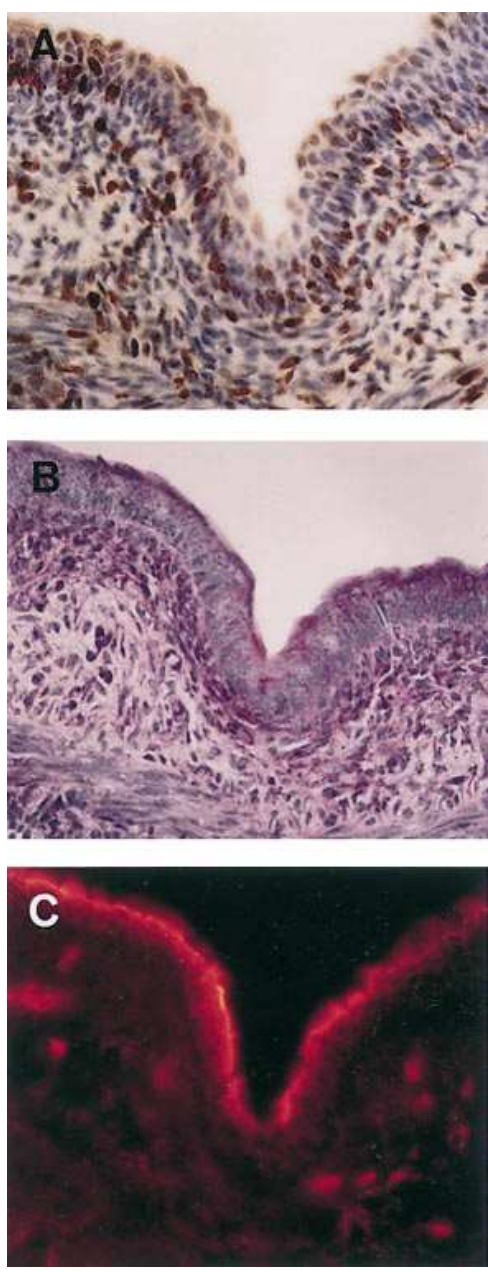
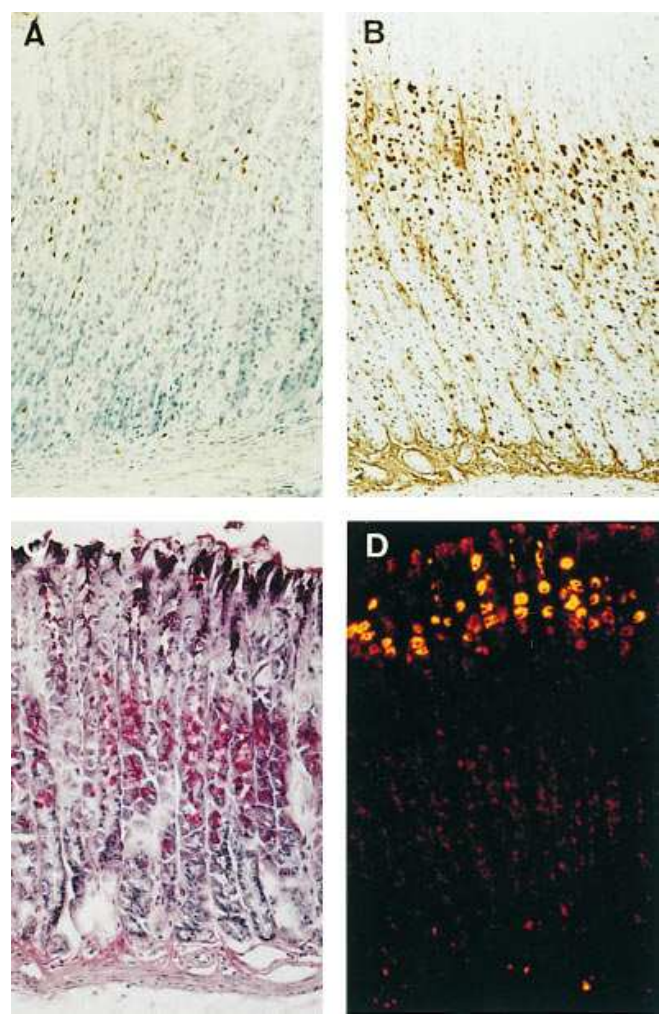

Figure 2. Characterization of adult rat gastric mucosa. Gastric mucosa was obtained from a young adult rat at postnatal day 35 . The same staining procedures as in Fig. 1 were performed. $(A)$ Immunostaining of BrdU. BrdU-incorporated cells were mostly distributed at a third level of the gastric unit. A few positive cells were scattered at the neck region of the gastric unit. (B) Immunostaining of PCNA. The cells with PCNA-stained nuclei were distributed as a wider layer than those with BrdU-positive nuclei. (C) PAS staining. PAS was strongly stained at the top pit cells along the surface epithelial lumen of the gastric glands and stained bright red along the middle portion of the gastric unit. $(D)$ Immunostaining of furin. Furin-positive cells were layered at the upper one fourth of the gastric glands. Small furin-positive cells were scattered at the subglandular region over the muscularis mucosae. epithelium.

At postneonatal day 35, the gastric gland unit has already matured morphologically and functionally, and forms a pit and crypt structure (47). Cell division takes place at the isthmus between the pit and glandular crypt of the gastric unit (1). The cells with BrdU-incorporated nuclei were localized to an isthmus between the pit and neck cell regions, which was approximately a third level of the gastric gland unit (Fig. $2 A$ ), as was similarly shown by the incorporation of $\left[{ }^{3} \mathrm{H}\right]$ thymidine (1). For BrdU staining, we treated formaldehyde to denature doublestranded DNA to a single one so that gastric glands look thinner than the other stainings (Fig. $2 A$ vs. $2, B-D$ ). PCNA is known as a DNA-tracking protein required for the rapid and processive replication of DNA by the polymerases $\delta$ and $\epsilon$ (48). PCNA is highly expressed at the $\mathrm{S}$ phase of the cell cycle. PCNA-positive cells were mostly localized to a third level of the gastric glands, as were BrdU-positive cells, but the PCNApositive cell layer was distributed wider than the BrdU-positive cell layer (Fig. 2, $A$ and $B$ ). PAS staining revealed a strong dark-red pattern at the top pit cells and a bright-red pattern at the cells along the middle portion of the gastric unit (Fig. $2 C$ ). The stained cells may represent surface mucous cells at the top, and mucous neck cells at the middle portion (1). This PAS
A
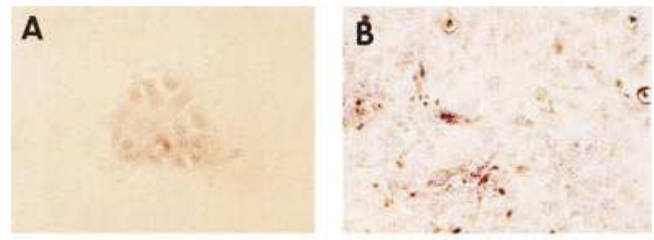

C
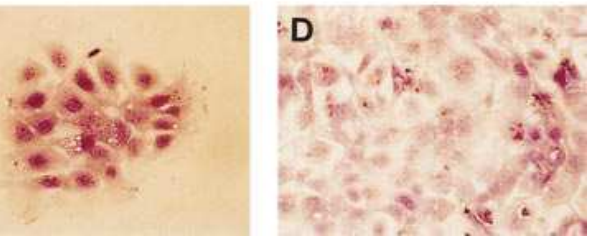

Figure 3. PAS staining of GSM06 cells cultured under various conditions. (A) $33^{\circ} \mathrm{C}$, low cell density. (B) $33^{\circ} \mathrm{C}$, high cell density. (C) $39^{\circ} \mathrm{C}$, low cell density. $(D) 39^{\circ} \mathrm{C}$, high cell density. PAS staining was positive at $39^{\circ} \mathrm{C}$ in both low and high cell densities. The staining covered whole cytoplasms and nuclei, but was not specifically localized in the secretory granules. 

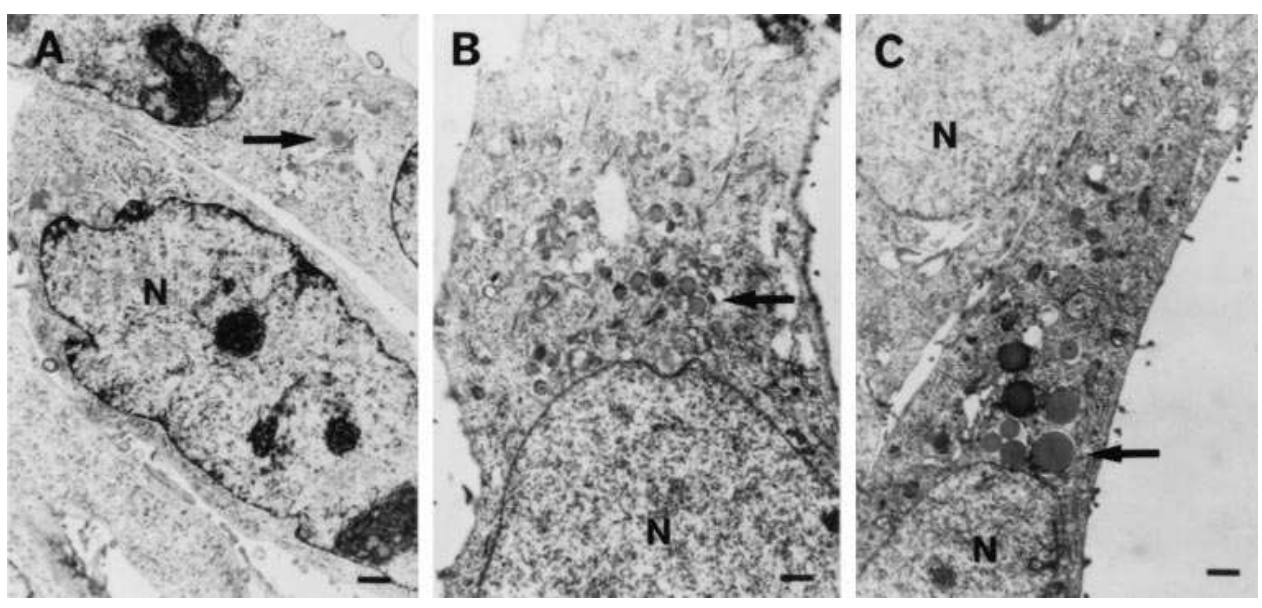

Figure 4. Electron microscopy of GSM06 cells. GSM06 cells were observed by electron microscopy under the two distinct conditions. (A) $33^{\circ} \mathrm{C}$. $(B$ and $C) 39^{\circ} \mathrm{C}$. N, nucleus. Bars indicate $1 \mu \mathrm{m}$. At $33^{\circ} \mathrm{C}$ only a few granules were visible $(A$, arrow $)$. In contrast, at $39^{\circ} \mathrm{C}$, 500-600-nm granules appeared in many cells $(B$, arrow). Some cells contained larger granules up to $1,250 \mathrm{~nm}(C$, arrow $)$. Most granules contained homogeneous light materials in the center with dark materials around the outer circle.

staining pattern did not change even after diastase treatment. Furin was stained as a distinct zonal layer around the upper one fourth of the gastric glands, but unlike PAS staining, the top pit cell region was not stained (Fig. $2 \mathrm{D}$ ). The furin-positive cell layer was located from the higher cell-proliferative zone to less proliferative pit cell region. Some cells appeared to be located in both the furin-positive layer and the cell proliferating zone. Thus, furin seemed to be expressed in the late stage or immediately poststage of cell division in embryonal and adult rat gastric mucosa.

PAS staining of GSM06 cells. A GSM06 cell line was established by the transformation with temperature-sensitive SV40 $\mathrm{T}$ antigen (25). The cells grow to confluency at $33^{\circ} \mathrm{C}$, whereas the cells stop growing at $39^{\circ} \mathrm{C}$. We characterized the cells with PAS staining by placing them at 33 or $39^{\circ} \mathrm{C}$; cells were stained either at high density (almost confluent) or low density ( $1 / 10$ of a confluent density). At $33^{\circ} \mathrm{C}$ and low cell density, the cells were not positive for PAS staining (Fig. $3 A$ ). When the cells became confluent at $33^{\circ} \mathrm{C}$, PAS-positive materials were not visible yet (Fig. $3 B$ ). However, when cells were kept confluent over $3 \mathrm{~d}$, PAS-positive materials appeared as described previously $(25,26)$. In contrast, when the cells were transferred from 33 to $39^{\circ} \mathrm{C}$ for $48 \mathrm{~h}$, the cells became clearly positive for PAS staining in low or high cell density (Fig. 3, $C$ and $D$ ). Thus, we noted that the higher temperature induced the expression of PAS-positive materials in the GSM06 cells both at low and high cell density.

Electron microscopy of GSM06 cells. Development of progenitor cells to mature pit cells via a pre-pit cell stage is charac- terized by the appearance and increase of mucous granules (2). These granules are positive for PAS staining $(19,20)$. We examined the presence of mucous granules in the GSM06 cells cultured at 33 and $39^{\circ} \mathrm{C}$. The cells at $33^{\circ} \mathrm{C}$ contained a few secretory granules, indicating that the cells are probably in an early pre-pit cell stage, but not in a granule-free progenitor cell stage, as Karam and Leblond described previously (Fig. $4 \mathrm{~A}$ ) $(1,2)$. When the cells were placed at $39^{\circ} \mathrm{C}$, a fair number of secretory granules appeared in the cytoplasm (Fig. 4, $B$ and $C$ ). Granules were various in diameter up to $\sim 1,250 \mathrm{~nm}$. At $39^{\circ} \mathrm{C}$ most cells contained 500-600-nm granules (Fig. 4 B, arrow). Some cells contained much larger granules, up to $1,250 \mathrm{~nm}$ (Fig. $4 C$, arrow). Some granules contained dark materials at their outer circle with light materials in the center (Fig. 4 B, arrow), others displayed homogeneous light materials (Fig. $4 C$, arrow). However, even at $39^{\circ} \mathrm{C}$ no cells displayed as many granules as seen in the mature pit cells (2). Thus, the number of secretory granules suggests that the cells appeared to develop from an early pre-pit cell stage to a more advanced prepit stage and exhibited embryonic features characteristic of rat gastric mucosa at gestational days $18-21(45,46)$.

Expression of furin. We examined the expression of furin in the GSM06 cells by Northern and Western blotting, and immunocytochemistry. In the Northern blot of furin, the message was at high levels at $33^{\circ} \mathrm{C}$ in both low and high cell densities, and the message at low density was a little stronger than that high density (Fig. $5 A$, lanes 1 and 2). In contrast, the message was at low levels at $39^{\circ} \mathrm{C}$ in both low and high densities (Fig. $5 A$, lanes 3 and 4 ). In the Western blot of furin, the band ap-

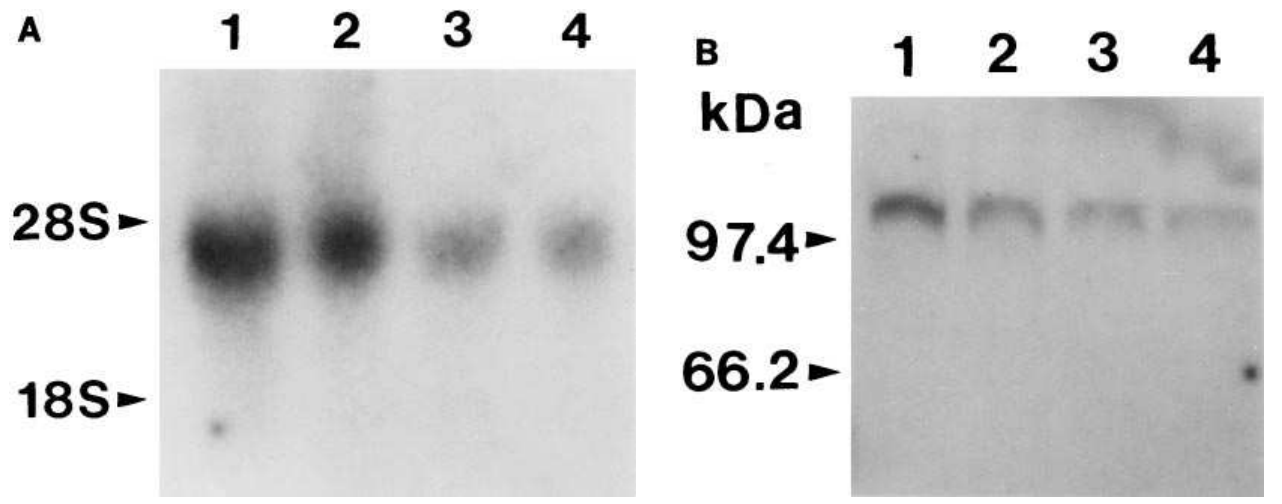

Figure 5. Expression of furin. (A) Northern blot. Lane $1,33^{\circ} \mathrm{C}$, low cell density. Lane $2,33^{\circ} \mathrm{C}$, high cell density. Lane $3,39^{\circ} \mathrm{C}$, low cell density. Lane $4,39^{\circ} \mathrm{C}$, high cell density. (B) Western blot. Lane $1,33^{\circ} \mathrm{C}$, low cell density. Lane $2,33^{\circ} \mathrm{C}$, high cell density. Lane $3,39^{\circ} \mathrm{C}$, low cell density. Lane $4,39^{\circ} \mathrm{C}$, high cell density. By the two different blotting methods, the blot at $33^{\circ} \mathrm{C}$ in low cell density was the strongest, while the blot at $39^{\circ} \mathrm{C}$ in high cell density was the weakest. 

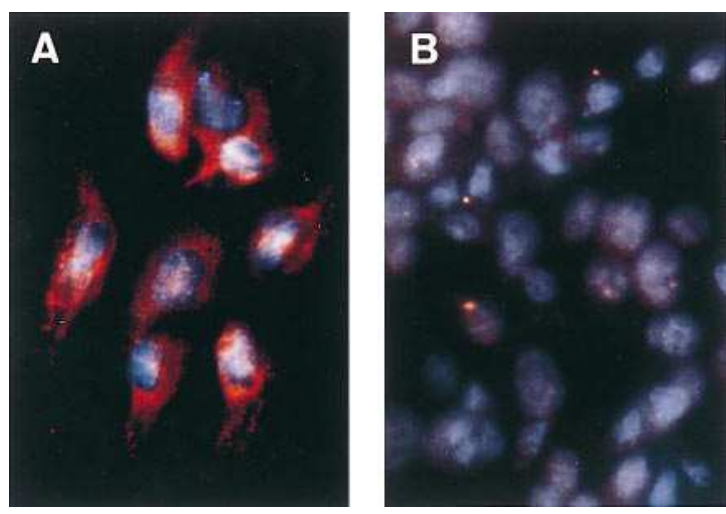

Figure 6. Immunostaining of furin in GSM06 cells. $(A) 33^{\circ} \mathrm{C}$, low cell density. $(B) 39^{\circ} \mathrm{C}$, high cell density. Strong immunostaining of furin was observed in the cells at $33^{\circ} \mathrm{C}$ in low cell density. Note that the staining was markedly decreased in the cells cultured at $39^{\circ} \mathrm{C}$ in high cell density. Nuclei were stained as blue with $4^{\prime}, 6^{\prime}$-diamidine-2-phenylindole-dihydrochloride.

peared at a little over $97.4 \mathrm{kD}$. Furin was strongest in the cells cultured at $33^{\circ} \mathrm{C}$ in low density, followed by conditions at $33^{\circ} \mathrm{C}$ in high density, and lastly at $39^{\circ} \mathrm{C}$ in both low and high densities (Fig. $5 \mathrm{~B}$ ). Thus, the tendency of furin expression was almost similar between the mRNA and protein. The immunocytochemical study showed that the cells at $33^{\circ} \mathrm{C}$ in low density displayed a strong staining of furin with a localization pattern of the Golgi stacks as reported before $(22,28)$ (Fig. $6 A$ ). On the other hand, negligible staining of furin was observed in the cells at $39^{\circ} \mathrm{C}$ in high cell density (Fig. $6 \mathrm{~B}$ ). Thus, furin expression was significantly different between these distinct conditions.

Immunoblot of TGF $\alpha$. We then examined the immunoblot of TGF $\alpha$ under the same conditions used for the furin immunoblotting. The immunoblot of TGF $\alpha$ appeared at a little under $6.5 \mathrm{kD}$, which may indicate the active form of 50 amino
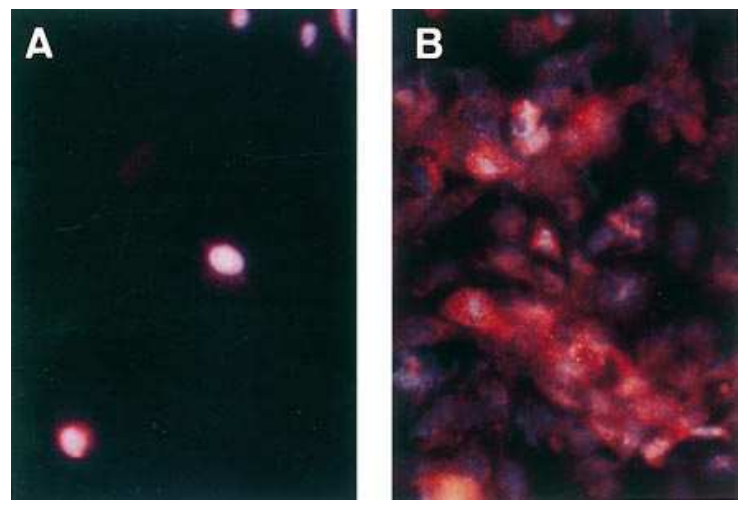

Figure 8. Immunostaining of furin in the GSM06 cells expressing sense or antisense furin cDNA. Sense or antisense furin cDNA was expressed by placing the cells for $48 \mathrm{~h}$ in culture with or without $100 \mu \mathrm{M} \mathrm{ZnCl}_{2}$. The cells were stained after culture with $\mathrm{ZnCl}_{2}$. $(A)$ GSM06 cells expressing an antisense furin DNA in low cell density at $33^{\circ} \mathrm{C}$. Note that the furin staining is negligible compared with that in Fig. $6 A$. $(B)$ GSM06 cells expressing a sense furin DNA in high cell density at $39^{\circ} \mathrm{C}$. Note that the furin staining is clearly visible in almost half the population of cells compared with that in Fig. $6 B$.
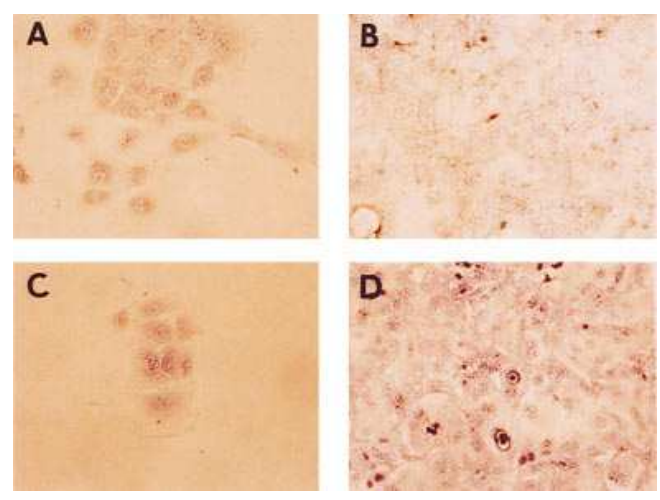

Figure 9. PAS staining of GSM06 cells expressing sense furin cDNA. Furin-expressing GSM06 cells were cultured for PAS staining under the same conditions as in Fig. 3. (A) $33^{\circ} \mathrm{C}$, low cell density. (B) $33^{\circ} \mathrm{C}$, high cell density. $(C) 39^{\circ} \mathrm{C}$, low cell density. $(D) 39^{\circ} \mathrm{C}$, high cell density. PAS staining was only faint even at $39^{\circ} \mathrm{C}$ in both low and high cell densities. Note the difference between Figs. 9 and 3.

acid TGF $\alpha$. TGF $\alpha$ is known to be formed as the $20-22 \mathrm{kD}$ precursor, and then processed to a $6-\mathrm{kD}$ form by way of several intermediate precursors (49). Although we observed faint bands at precursor-size positions by longer x-ray film exposure, the major bands appeared close to a $6-\mathrm{kD}$ position. As to immunostaining, the strongest signals were present in the high density cells at $39^{\circ} \mathrm{C}$, and then the high density cells at $33^{\circ} \mathrm{C}$, followed closely by the low density cells at $39^{\circ} \mathrm{C}$, and lastly the low density cells at $33^{\circ} \mathrm{C}$ (Fig. 7). We observed one more extra band under the major one at $39^{\circ} \mathrm{C}$ in high density (Fig. 7, lane 4). This extra band was observed also in the previous work (49), and may reveal a more processed form of the major band. TGF $\alpha$ expression in these cell conditions appeared to be ranked in an opposite order from the furin expression and PAS-positive material formation.

Effect of sense or antisense furin $c D N A$ on the expression of furin, PAS-positive materials, and TGF $\alpha$. We used GSM06 cells transfected with a sense or antisense furin cDNA expression vector to examine the appearance of PAS-positive materi-
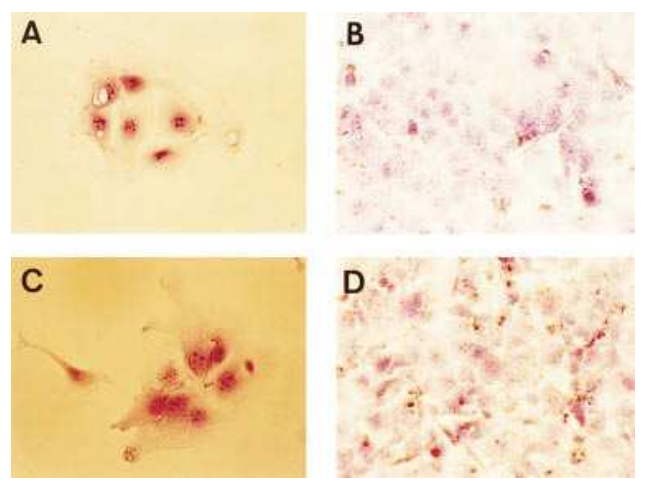

Figure 10. PAS staining of GSM06 cells expressing antisense furin cDNA. Antisense furin-expressing GSM06 cells were cultured for PAS staining under the same conditions as in Fig. 3. (A) $33^{\circ} \mathrm{C}$, low cell density. $(B) 33^{\circ} \mathrm{C}$, high cell density. $(C) 39^{\circ} \mathrm{C}$, low cell density. $(D)$ $39^{\circ} \mathrm{C}$, high cell density. PAS staining was positive even at $33^{\circ} \mathrm{C}$ in both low and high cell densities. Note the difference between Figs. 10 and 3. 


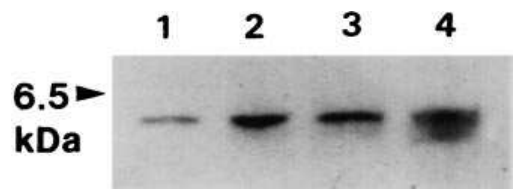

Figure 7. Immunoblot of TGF $\alpha$. The immunoblot of TGF $\alpha$ was carried out in the same conditions as in Fig. 5 B. Lane $1,33^{\circ} \mathrm{C}$, low cell density. Lane $2,33^{\circ} \mathrm{C}$, high cell density. Lane $3,39^{\circ} \mathrm{C}$, low cell density. Lane $4,39^{\circ} \mathrm{C}$, high cell density.

als and the expression of TGF $\alpha$. The sense or antisense furin cDNA was placed under a mouse metallothionein promoter that can be induced by the addition of $\mathrm{ZnCl}_{2}$ in the culture medium. With this regulatable expression system, the expression of antisense furin cDNA may suppress endogenous furin, whereas the expression of sense furin cDNA may result in the additive increase of furin. The $\mathrm{Zn}^{2+}$-inducible expression of furin was confirmed by immunocytochemistry. As shown in Fig. $8 B$, furin was immunostained when the sense furin cDNA was expressed in the cells with $100 \mu \mathrm{M} \mathrm{ZnCl}$, even at high cell density at $39^{\circ} \mathrm{C}$, where furin was not expressed in unaltered GSM06 cells (Fig. $6 \mathrm{~B}$ ). Overexpressed furin was colocalized with the TGN marker protein TGN38 (data not shown). Almost half of the cells became furin positive in their condition. In contrast, in the cells with the induction of the antisense furin cDNA, furin was only faintly immunostained even at low cell density at $33^{\circ} \mathrm{C}$ (Fig. $8 \mathrm{~A}$ ), where furin was strongly stained in unaltered cells (Fig. $6 A$ ). Thus, we could control furin expression by the induction of sense or antisense furin cDNA.

With the expression of sense furin RNA, the cells exhibited virtually no PAS-positive staining at $33^{\circ} \mathrm{C}$ either at low or high density (Fig. 9, $A$ and $B$ ); unaltered GSM06 cells also did not show PAS-positive staining (Fig. $3, A$ and $B$ ). At $39^{\circ} \mathrm{C}$, PASpositive materials appeared only faintly in low and high density cells (Fig. 9, $C$ and $D$ ), unlike the contrasting positive staining in the corresponding culture conditions shown in Fig. $3, C$ and $D$. On the contrary, expression of antisense furin DNA induced the appearance of PAS staining in both the low and high density cells at $33^{\circ} \mathrm{C}$ (Fig. 10, $A$ and $B$ ), whereas unaltered cells did not stain PAS-positive (Fig. 3, $A$ and $B$ ). Furthermore, the expression of PAS-positive materials appeared to be augmented at $39^{\circ} \mathrm{C}$ in both low and high cell densities (Fig. 10, $C$ and $D$ ) compared with the corresponding conditions of the cells shown in Fig. 3, $C$ and $D$. Thus, judging from the formation of PAS-positive materials, furin expression

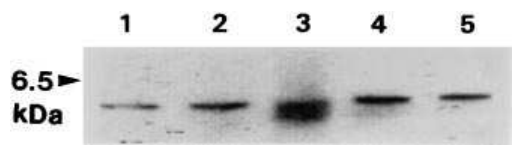

Figure 11. Immunoblot of TGF $\alpha$ from the GSM06 cells expressing sense or antisense furin cDNA. Sense or anti-

sense furin cDNA was expressed by placing the cells for $48 \mathrm{~h}$ in culture with or without $100 \mu \mathrm{M} \mathrm{ZnCl}_{2}$. The cell lysate was obtained for TGF $\alpha$ immunoblot from the cells after culture with or without 100 $\mu \mathrm{M} \mathrm{ZnCl}$. Lane 1, unaltered GSM06 cells. Lanes 2 and 3, GSM06 cells expressing an antisense furin cDNA without $100 \mu \mathrm{M} \mathrm{ZnCl}_{2}$ (lane 2) and with $100 \mu \mathrm{M} \mathrm{ZnCl}_{2}$ (lane 3). Note that TGF $\alpha$ immunoblot was increased with antisense furin cDNA expression (lane 2 vs. 3). Lanes 4 and 5, GSM06 cells expressing a sense furin cDNA without $100 \mu \mathrm{M} \mathrm{ZnCl}_{2}$ (lane 4) and with $100 \mu \mathrm{M} \mathrm{ZnCl}_{2}$ (lane 5). Note that TGF $\alpha$ immunoblot was decreased with sense furin cDNA expression (lane 4 vs. 5). maintained the cells in a less differentiated state, whereas furin suppression facilitated the differentiation of the cells.

The immunoblot of TGF $\alpha$ showed that TGF $\alpha$ expression increased in the cells in which antisense furin cDNA was induced with $\mathrm{ZnCl}_{2}$ (Fig. 11, lane 3). On the contrary, with the induction of the sense furin cDNA, the TGF $\alpha$ expression was slightly diminished (Fig. 11, lane 5). Thus, the appearance of the PAS-positive materials, as well as the expression of TGF $\alpha$, were negatively correlated with furin expression.

Effect of furin expression on the growth of GSM06 cells. Since furin expression is instrumental in the differentiation process of GSM cells, we examined whether furin expression affects the growth of GSM06 cells. We used two methods to regulate furin expression: the first was the GSM cell line expressing the sense or antisense furin cDNA used in the above experiments, the other was a nuclease-resistant sense or antisense furin oligonucleotide. In the first regulation system, cell growth was compared between the cells expressing sense or antisense furin cDNA $48 \mathrm{~h}$ after the addition of $\mathrm{ZnCl}_{2}$. We initially confirmed that both unaltered GSM06 cells and empty vector pMEP4-introduced GSM06 cells did not exhibit a significant change in their growth rate with or without $\mathrm{ZnCl}_{2}$ up to a $100-\mu \mathrm{M}$ concentration. The cells proliferated with a similar growth rate as unaltered GSM06 cells (Fig. 12), although we expected an enhanced growth of the cells due to increased furin expression. In this experiment, we had to plate cells less confluent to observe the cell growth, which resulted in the extensive furin expression. This additional expression may have induced no further effect on cell growth. On the other hand, when the antisense cDNA was induced, the growth was significantly retarded at 80 to $100 \mu \mathrm{M} \mathrm{ZnCl}_{2}$ (Fig. 12).

In the second regulation system using oligonucleotides, we used a serum-free medium for cell culture so that we could exclude the serum effect on cell growth. In a $\mathrm{Zn}^{2+}$-inducible expression system, we had to add serum to the cell culture to alleviate $\mathrm{Zn}^{2+}$ cell toxicity. The growth was evaluated $48 \mathrm{~h}$ after the addition of sense or antisense oligonucleotide. When up to

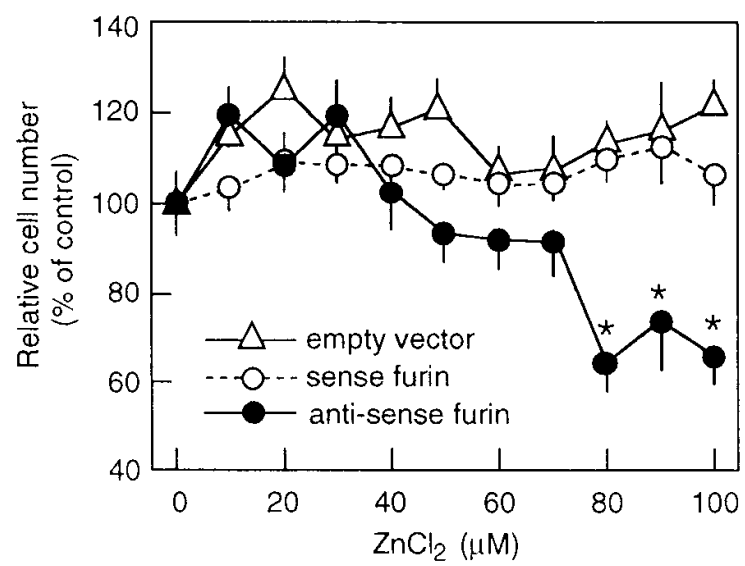

Figure 12. Growth of sense or antisense furin cDNA-expressing GSM06 cells. Cell growth was measured by using the dye WST-1 as described in Methods. The cells were cultured for $48 \mathrm{~h}$ in the presence of $100 \mathrm{mM} \mathrm{ZnCl}_{2}$. Open circle, the cells expressing a sense furin cDNA. Closed circle, the cells expressing an antisense furin cDNA. Open triangle, the cells expressing an empty vector pMEP4 alone. The growth was retarded only when the antisense furin cDNA was expressed. $* P<0.01$. 


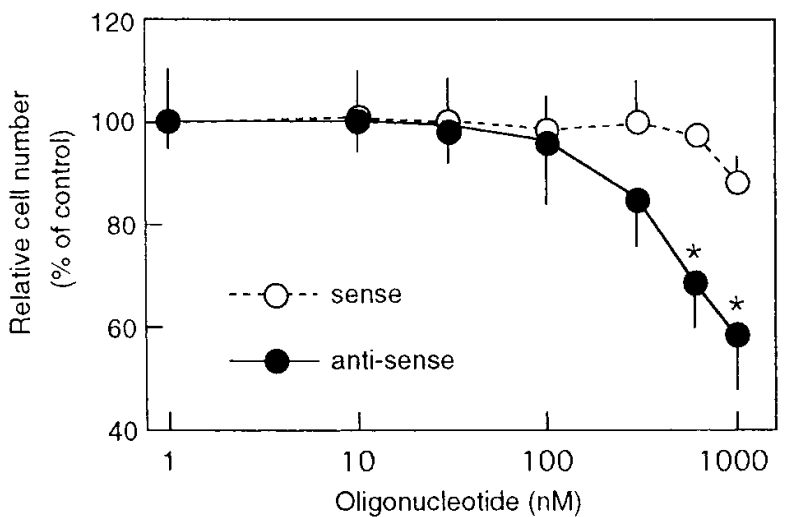

Figure 13. Effect of a sense or antisense oligonucleotide encoding a part of the furin-coding sequence on the growth of GSM06 cells. The GSM06 cells were cultured in a serum-free medium PI-1000 with a sense or antisense furin oligonucleotide $(1,10,30,100,300,600,1,000$ $\mathrm{nM})$. Cell growth was measured by using the dye WST-1. Open circle, the culture in the presence of a sense furin oligonucleotide. Closed circle, the culture in the presence of an antisense furin oligonucleotide. The growth was more retarded in the culture with an antisense oligonucleotide than with a sense oligonucleotide (300-1,000 nM). $* P<0.01$

$600 \mathrm{nM}$ of the sense oligonucleotide was added to the culture, the growth was not retarded, but growth did decrease with $1,000 \mathrm{nM}$ (Fig. 13). In contrast, when the antisense oligonucleotide was used, growth slowed slightly at $300 \mathrm{nM}$, and then was significantly retarded with increased oligonucleotide concentrations (Fig. 13). Thus, with the two regulation systems, we confirmed that furin suppression decreased the growth rate of the cells.

Growth-promoting effect of the culture media conditioned with the sense and antisense furin oligonucleotides. Because the growing GSM06 cells expressed a high level of furin and because furin suppression resulted in the retardation of the cell growth, we hypothesized that the cells might secrete bioactive growth factors that are converted from their precursors by furin cleavage. To examine this possibility, we prepared the conditioned media by culturing the cells with the sense or antisense furin oligonucleotide, expecting that the cells release such growth-promoting factors in the medium. We used serum-free PM-1000 medium because serum itself contains a high level of growth-promoting factors and may obscure the effect of newly generated growth factors. We prepared the three conditioned media: C, S, and AS. C was prepared without addition of oligonucleotides, while the $\mathrm{S}$ and AS media were prepared by adding the sense or antisense furin oligonucleotide to the GSM06 cell culture, respectively, at a final concentration of $600 \mathrm{nM}$ and incubated for $24 \mathrm{~h}$. Each medium was concentrated with an Amicon membrane filter concentration system. With this concentration process, most oligonucleotides passed through a membrane with a continuous flow of PM-1000 serum-free medium because we could not detect any leftover oligonucleotide by an ethidium bromide detection method. When conditioned medium $\mathrm{C}$ or $\mathrm{S}$ was used for the GSM06 culture, the cells grew more than those in the cell culture using nonconditioned PM-1000 (Fig. 14, NC). As predicted from Fig. 13, the conditioned medium prepared with the sense oligonucleotide had a similar effect on the cell growth to

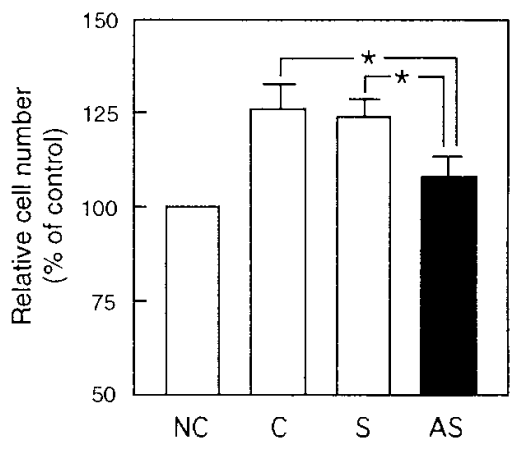

Figure 14. Effect of conditioned media from the culture with the sense or antisense furin oligonucleotide on the growth of GSM06 cells. Conditioned media were prepared by culturing the GSM06 cells in the absence of both oligonucleotides $(C)$, in the presence of $600 \mathrm{nM}$

sense oligonucleotide $(S)$, or in the presence of antisense oligonucleotide $(A S)$. Unaltered GSM06 cells were cultured with nonconditioned PM-1000 medium NC, the conditioned media C, S, or AS. The cell number was assessed with the dye WST-1. NC, culture of the nonconditioned assay medium. $\mathrm{C}$, culture with the conditioned medium without oligonucleotides. S, culture with the conditioned medium in the presence of the sense furin oligonucleotide. AS, culture with the conditioned medium in the presence of the antisense furin oligonucleotide. The growth of GSM06 cells was significantly retarded by the conditioned medium prepared with the antisense oligonucleotide compared with the conditioned medium with or without the sense oligonucleotide. ${ }^{*} P<0.01$.

that prepared without the oligonucleotide. When the AS-conditioned medium was used, however, cell growth was retarded (Fig. 14). This result suggests that suppression of furin may have reduced the conversion of growth factor precursors to their bioactive forms.

\section{Discussion}

The present study demonstrated that at the permissive temperature $\left(33^{\circ} \mathrm{C}\right)$ of a temperature-sensitive SV40 large T antigen, the gastric surface mucous cell line GSM06 cells had undifferentiated features with high expression of the proprotein processing endoprotease furin, negligible production of PASpositive materials, poor formation of secretory granules, and a low expression of TGF $\alpha$. At the nonpermissive temperature $\left(39^{\circ} \mathrm{C}\right)$, on the other hand, they exhibited differentiated features with furin suppression, production of PAS-positive materials, appearance of many secretory granules, and increased expression of TGF $\alpha$. When furin was induced in the GSM06 cells, the cells produced no PAS-positive materials and less $\mathrm{TGF} \alpha$, even in a differentiated condition (confluent state at $39^{\circ} \mathrm{C}$ ). Furin-suppressed cells, however, produced PAS-positive materials and a higher amount of $\mathrm{TGF} \alpha$, even in a less-differentiated condition (nonconfluent state at $33^{\circ} \mathrm{C}$ ). Furthermore, furin suppression retarded cell growth, suggesting that furin may be instrumental in the growth of gastric surface mucous cells.

At gestational day 18, fetal rat furin is localized along an outer layer of the epithelial cells that cover the gastric mucosa (Fig. $1 C$ ). At this stage, gastric epithelial cells are remarkably active in cell proliferation (Fig. $1 A$ ), but are poor in the production of PAS-positive materials (Fig. $1 B$ ). Surface mucous cells contain a trace of secretory granules at gestational days 18 and 19, but at gestational days 20 and 21, many granules appeared in the cytoplasm $(45,46)$. Coincidentally, TGF $\alpha$ appeared faintly after the gestational day 20 in rat surface epithe- 
lial cells (49). In the gastric mucosa of adult rats (postnatal day 35), furin-positive cells were layered at the upper one fourth of the gastric glands (Fig. $2 \mathrm{D}$ ). The cell proliferating zone identified by BrdU incorporation and PCNA staining was located a little lower than a furin-positive cell layer, but some cells appeared to stay in the proliferative zone with furin-positive staining (Fig. 2, $A, B$, and $D$ ). PAS-positive cells were distributed at both upper and lower sides of the furin-positive area (Fig. 2, $C$ and $D$ ). TGF $\alpha$ is expressed along a pit cell region from the pit region to the lumen $(13,14,49)$. Since furin-positive cells were localized to the upper cell proliferating zone and less proliferating pit cell region, furin may activate precursors for growth-related proteins.

A great amount of information has been obtained from culture cell studies since the primary culture of gastric surface mucous cells has been established $(10,16,19-21)$. Most of the information obtained has been important for interpreting the in vivo function of gastric mucous cells in the fundic mucosa. Caution should be used, however, when extrapolating information from the cell culture studies to the in vivo function of individual cells localized in the gastric glands. In gastric glands, surface mucous cells are composed of heterogeneous populations in their differentiation process and only a small fraction of the cells divide at the proliferative zone of the isthmus $(1,2)$. When the surface mucous cells are placed in primary culture, however, $\sim 50 \%$ of the cells are dividing by thymidine or BrdU incorporation, and many cells exhibit a decrease in PASpositive materials (10). In general, culture cells tend to lose their differentiated characteristics and instead acquire fetal stage-specific characteristics (22). Indeed, GSM06 cells at $33^{\circ} \mathrm{C}$ and fetal epithelial cells exhibit similar characteristics: a high level of furin expression, a negligible level of PAS-positive materials, a low level of TGF $\alpha$ production, and only a few secretory granules (45-47). Thus, we assume that GSM06 cells in a nonconfluent state at $33^{\circ} \mathrm{C}$ may correspond to the in vivo surface epithelial cells in the fetal stage around gestational day 18. In contrast, the cells in a confluent state at $39^{\circ} \mathrm{C}$ showed a negligible level of furin, the appearance of PAS-positive materials, a high level of TGF $\alpha$ production, and a considerable number of secretory granules. These characteristics indicate that the cells in this state may correspond to the in vivo cells at gestational days 20 and 21, rather than the gastric epithelial cells in the adult stage.

With these precautions in mind, we used the GSM06 cell line as a model for gastric surface mucous cells. We examined the role of furin in growth and differentiation by the use of PAS-positive materials and TGF $\alpha$ as a differentiation marker. For this purpose, we generated two modified cell lines, one was transformed with a mouse furin cDNA vector, and the other with an antisense furin cDNA vector that was designed to suppress native sense furin RNA-directed protein synthesis. The expression of these vectors was controlled under a metallothionein promoter, which was activated by zinc ions (22). With the sense furin RNA expression, GSM06 cells exhibited undifferentiated characteristics, virtually no appearance of PASpositive materials, and a low level of TGF $\alpha$ expression. As long as furin was expressed in the cells, PAS-positive materials did not appear, even in the differentiation state, in high cell density and at the nonpermissive temperature of $39^{\circ} \mathrm{C}$. On the contrary, expression of antisense furin RNA in GSM06 cells caused the induction of PAS-positive materials and TGF $\alpha$ production even in low cell density and at the permissive tempera- ture of $33^{\circ} \mathrm{C}$. Moreover, expression of antisense furin RNA decreased the growth rate of GSM06 cells. These findings indicate that furin expression keeps GSM06 cells in an undifferentiated state. However, the overexpression of furin did not increase cell growth any further. In growing cells, endogenous furin may have been expressed enough to induce the full capacity of cell growth.

Since furin is known to convert precursors for growthrelated proteins to their active forms $(28-33,35-37)$, we determined whether the furin-suppressing cells produce fewer bioactive forms of growth factors. We examined the effect of conditioned medium from the furin-suppressing cells on intact GSM06 cells. Conditioned medium from the cell culture in the presence of the antisense oligonucleotide caused decreased DNA synthesis in GSM06 cells as compared with the control conditioned medium from the cell culture in the presence or absence of the sense oligonucleotide, suggesting that furin suppression may generate less conversion of growth factor precursors. Recently, it was demonstrated that furin recycles between the TGN and plasma membrane (50). Furin possesses an important signal for this recycling in its 58 amino acid cytoplasmic tail (51). When furin is increased, the conversion of growth factor precursors may be facilitated. In addition, the constitutive pathway may enlarge due to more active furin recycling.

In fetal gastric mucosa, furin appears to convert growthpromoting factor precursors to their active forms, but such growth factor precursors with a furin-cleavable processing site remain to be identified. The processing of TGF $\alpha$ precursor to the small 50 amino acid peptide is an important step for growth control (49), but the TGF $\alpha$ precursor does not possess furincleavable sites (52). Furthermore, TGF $\alpha$ appears after gestational day 20 in the rat fetal gastric epithelial cells (53). Thus, it is likely that some other growth-promoting peptides with a furin-cleavable site are involved in the active proliferation of the fetal gastric epithelial cells. Although the substrates for furin are uncertain, we suggest that furin is important in the growth of the gastric mucosa in both fetal and adult stages by converting yet unknown precursors to their active forms.

\section{Acknowledgments}

We are grateful to Ms. Mina Takei for her secretarial assistance.

This work is supported by grants-in-aid from the Ministry of Education, Science and Culture, the Tokyo Biochemical Research Foundation, and the Kanae Foundation of Research for New Medicine.

\section{References}

1. Karam, S.M., and C.P. Leblond. 1993. Dynamics of epithelial cells in the corpus of the mouse stomach. I. Identification of proliferative cell types and pinpointing of the stem cell. Anat. Rec. 236:259-279.

2. Karam, S.M., and C.P. Leblond. 1993. Dynamics of epithelial cells in the corpus of the mouse stomach. II. Outward migration of pit cells. Anat. Rec. 236: 280-296.

3. Boland, C.R., E.R. Kraus, J.M. Scheiman, C. Black, G.D. Deshmukh, and W.O. Dobbins III. 1990. Characterization of mucous cell synthetic functions in a new primary canine gastric mucous cell culture system. Am. J. Physiol. 258:G774-G787.

4. Goddard, P.J., Y.-C.J. Kao, and L.M. Lichtenberger. 1990. Luminal surface hydrophobicity of canine gastric mucosa is dependent on a surface mucous gel. Gastroenterology. 98:361-370.

5. Soll, A.H., D.A. Amirian, L.P. Thomas, T.J. Reedy, and J.D. Elashoff. 1984. Gatrin receptors on isolated canine parietal cells. J. Clin. Invest. 73:14341447.

6. Johnson, L.R. 1988. Regulation of gastrointestinal mucosal growth. Physiol. Rev. 68:456-502

7. Allen, A., G. Flemstrom, A. Garner, and E. Kivilaakso. 1993. Gas- 
troduodenal mucosal protection. Physiol. Rev. 73:823-857.

8. Kelly, S.M., and J.O. Hunter. 1990. Epidermal growth factor stimulates synthesis and secretion of mucus glycoproteins in human gastric mucosa. Clin. Sci. 79:425-427.

9. Beauchamp, R.D., J.A. Barnard, C.M. McCutchen, J.A. Cherner, and M. Renewal. 1989. Localization of transforming growth factor $\alpha$ and its receptor in gastric mucosal cells. J. Clin. Invest. 84:1017-1023.

10. Chen, M.C., A.T. Lee, and A.H. Soll. 1991. Mitogenic response of canine fundic epithelial cells in short-term culture to transfoming growth factor $\alpha$ and insulinlike growth factor I. J. Clin. Invest. 87:1716-1723.

11. Murayama, Y., J. Miyagawa, S. Higashiyama, S. Kondo, M. Yabu, K. Isozaki, Y. Kayanoki, S. Kanayama, Y. Shinomura, N. Taniguchi, and Y. Matsuzawa. 1995. Localization of heparin-binding epidermal growth factor-like growth factor in human gastric mucosa. Gastroenterology. 109:1051-1059.

12. Takahashi, M., S. Ota, T. Shimada, E. Hamada, T. Kawabe, T. Okudaira, M. Matsumura, N. Kaneko, A. Terano, T. Nakamura, and M. Omata. 1995. Hepatocyte growth factor is the most potent endogenous stimulant of rabbit gastric epithelial cell proliferation and migration in primary culture. $J$. Clin. Invest. 95:1994-2003.

13. Nasim, M.M., D.M. Thomas, M.R. Alison, and M.I. Filipe. 1992. Transforming growth factor $\alpha$ expression in normal gastric mucosa, intestinal metaplasia, dysplasia and gastric carcinoma-an immunohistochemical study. Histopathology (Oxf.). 20:339-343

14. Thomas, D.M., M.M. Nasim, W.J. Gullick, and M.R. Alison. 1992. Immunoreactivity of transforming growth factor alpha in the normal adult gastrointestinal tract. Gut. 33:628-631.

15. Dempsey, P.J., J.R. Goldenring, C.J. Soroka, I.M. Modlin, R.W. McClure, C.D. Lind, D.A. Ahlquist, M.R. Pittelkow, D.C. Lee, E.P. Sandgren, et al. 1992. Possible role of transforming growth factor $\alpha$ in the pathogenesis of Ménétrier's disease: supportive evidence from humans and transgenic mice. Gastroenterology. 103:1950-1963.

16. Chen, M.C., A.T. Lee, W.E. Karnes, D. Avedian, M. Martin, J.M. Sorvillo, and A.H. Soll. 1993. Paracrine control of gastric epithelial cell growth in culture by transforming growth factor- $\alpha$. Am. J. Physiol. 264:G390-G396.

17. Sottili, M., C. Sternini, N.C. Brecha, E. Lezoche, and J.H. Walsh. 1992. Transforming growth factor $\alpha$ receptor binding sites in the canine gastrointestinal tract. Gastroenterology. 103:1427-1436.

18. Rutten, M.J., P.J. Dempsey, C.A. Luttropp, M.A. Hawkey, B.C. Sheppard, R.A. Crass, C.W. Deveney, and R.J. Coffey. 1996. Identification of an EGF/TGF- $\alpha$ receptor in primary cultures of guinea pig gastric mucous epithelial cells. Am. J. Physiol. 270:G604-G612.

19. Terano, A., K.J. Ivey, J. Stachura, S. Sekhon, H. Hosojima, W.N. McKenzie, W.J. Krause, and J.H. Wyche. 1982. Cell culture of rat gastric fundic mucosa. Gastroenterology. 83:1280-1291.

20. Matuoka, K., M. Tanaka, Y. Mitsui, and S.-I. Murota. 1983. Cultured rabbit gastric epithelial cells producing prostaglandin $\mathrm{I}_{2}$. Gastroenterology. 84: 498-505.

21. Fukamachi, H., M. Ichinose, S. Ishihama, S. Tsukada, S. Yasugi, K. Shiokawa, C. Furihata, S. Yonezawa, and K. Miki. 1994. Fetal rat glandular stomach epithelial cells differentiate into surface mucous cells which express cathepsin $\mathrm{E}$ in the absence of mesenchymal cells in primary culture. Differentiation. 56:83-89.

22. Kayo, T., Y. Sawada, Y. Suzuki, M. Suda, S. Tanaka, Y. Konda, J. Miyazaki, and T. Takeuchi. 1996. Proprotein-processing endoprotease furin decreases regulated secretory pathway-specific proteins in the pancreatic $\beta$ cell line MIN6. J. Biol. Chem. 271:10731-10737.

23. Frederiken, K., P.S. Jat, N. Valtz, D. Levy, and R. McKay. 1988. Immortalization of precursor cells from the mammalian CNS. Neuron. 1:439-448.

24. Jat, P.S., M.D. Noble, P. Ataliotis, Y. Tanaka, N. Yannoutsos, L. Larsen, and D. Kioussis. 1991. Direct derivation of conditonally immortal cell lines from an $\mathrm{H}$ - $2 \mathrm{~Kb}$-tsA58 transgenic mouse. Proc. Natl. Acad. Sci. USA. 88: 5096-5100.

25. Sugiyama, N., Y. Tabuchi, T. Horiuchi, M. Obinata, and M. Furusawa. 1993. Establishment of gastric surface mucous cell lines from transgenic mice harboring temperature-sensitive simian virus 40 large T-antigen gene. Exp. Cell Res. 209:382-387.

26. Tabuchi, Y., N. Sugiyama, T. Horiuchi, K. Furuhama, and M. Furusawa. 1996. Biological characterization of gastric surface mucous cell line GSM06 from transgenic mice harboring temperature-sensitive simian virus 40 large T-antigen gene. Digestion. 57:141-148.

27. Dohi, T., M. Nakasuji, K. Nakanishi, E. Yausgi, Y. Yuyama, N. Sugiyama, Y. Tabuchi, T. Horiuchi, and M. Oshima. 1996. Biochemical bases in differentiation of a mouse cell line GSN06 to gastric surface cells. Biochim. Biophys. Acta. 1289:71-78.

28. Bresnahan, P.A., R. Leduc, L. Thomas, J. Thorner, H.L. Gibson, A.J. Brake, P.J. Barr, and G. Thomas. 1990. Human fur gene encodes a yeast KEX2like endoprotease that cleaves Pro- $\beta-N G F$ in vivo. J. Cell Biol. 111:2851-2859.
29. Seidah, N.G., and M. Chrétien. 1992. Proprotein and prohormone convertases of the subtilisin family. Recent developments and future perspectives. Trends Endocrinol. Metab. 3:133-140.

30. Hatta, K., A. Nose, A. Nagafuchi, and M. Takeichi. 1988. Cloning and expression of cDNA encoding a neural calcium-dependent cell adhesion molecule: its identity in the cadherin gene family. J. Cell Biol. 106:873-881.

31. Marchand, P., J. Tang, G.D. Johnson, and J.S. Bond. 1995. COOH-terminal proteolytic processing of secreted and membrane forms of the $\alpha$ subunit of the metalloprotease meprin A. Requirement of the I domain for processing in the endoplasmic reticulum. J. Biol. Chem. 270:5449-5456.

32. Pei, D., and S.J. Weiss. 1995. Furin-dependent intracellular activation of the human stromelysin-3 zymogen. Nature (Lond.). 375:244-247.

33. Sato, H., T. Takino, Y. Okada, J. Cao, A. Shinagawa, E. Yamamoto, and M. Seiki. 1994. A matrix metalloproteinase expressed on the surface of invasive tumour cells. Nature (Lond.). 370:61-65.

34. Tsuda, T., K. Yoshida, T. Tsujino, H. Nakayama, G. Kajiyama, and E. Tahara. 1989. Coexpression of platelet-derived growth factor (PDGF) A-chain and PDGF receptor genes in human gastric carcinomas. Jpn. J. Cancer Res. 80: 813-817.

35. Dubois, C.M., M.-H. Laprise, M.F. Blanchette, L.E. Gentry, and R. Leduc. 1995. Processing of transforming growth factor $\beta 1$ precursor by human furin convertase. J. Biol. Chem. 270:10618-10624.

36. Bravo, D.A., J.B. Gleason, R.I. Sanchez, R.A. Roth, and R.S. Fuller. 1994. Accurate and efficient cleavage of the human insulin proreceptor by the human proprotein-processing protease furin. J. Biol. Chem. 269:25830-25837.

37. Komada, M., K. Hatsuzawa, S. Shibamoto, F. Ito, K. Nakayama, and N. Kitamura. 1993. Proteolytic processing of the hepatocyte growth factor/scatter factor receptor by furin. FEBS Lett. 328:25-29.

38. Sharp, R., M.W. Babyatsky, H. Takagi, S. Tagerud, T.C. Wang, D.E. Bockman, S.J. Brand, and G. Merlino. 1995. Transforming growth factor $\alpha$ disrupts the normal program of cellular differentiation in the gastric mucosa of transgenic mice. Development (Camb.). 121:149-161.

39. Kayo, T., Y. Konda, S. Tanaka, K. Takata, A. Koizumi, and T. Takeuchi. 1996. Developmental expression of proprotein-processing endoprotease furin in rat pancreatic islets. Endocrinology. 137:5126-5134.

40. Wijsman, J.H., J.-H. van Dierendonck, R. Keijzer, C.J.H. van de Velde, and C.J. Cornelisse. 1992. Immunoreactivity of proliferating cell nuclear antigen compared with bromodeoxyuridine incorporation in normal and neoplastic rat tissue. J. Pathol. 168:75-83.

41. Clark, G. 1981. Periodic acid leucofuchsin method. In Staining Procedures. G. Clark, editor. Williams and Wilkins Book Co., Baltimore, MD. 200-201.

42. Ishiyama, M., M. Shiga, K. Sasamoto, M. Mizoguchi, and P.G. He. 1993. A new sulfonated tetrazolium salt that produces a highly water-solubule formazan dye. Chem. Pharm. Bull. (Tokyo). 41:1118-1122.

43. Hatsuzawa, K., M., Hosaka, T. Nakagawa, M. Nagase, A. Shoda, K. Murakami, and K. Nakayama. 1990. Structure and expression of mouse furin, a yeast Kex2-related protease. J. Biol. Chem. 265:22075-22078.

44. van der Krol, A.R., J.N.M. Mol, and A.R. Stuitje. 1988. Modulation of eukaryotic gene expression by complementary RNA or DNA sequences. Biotechniques. 6:958-976.

45. Helander, H.F. 1969. Ultrastructure and function of gastric parietal cells in the rat during development. Gatroenterology. 56:35-52.

46. Helander, H.F. 1969. Ultrastructure and function of gastric mucoid and zymogen cells in the rat during development. Gatroenterology. 56:53-70.

47. Johnson, L.R. 1985. Functional development of the stomach. Annu. Rev. Physiol. 47:199-215.

48. Waga, S., and B. Stillman. 1994. Anatomy of a DNA replication fork revealed by reconstitution of SV40 DNA replication in vitro. Nature (Lond.). 369: 207-212.

49. Pandiella, A., and J. Massague. 1991. Cleavage of the membrane precursor for transforming growth factor alpha is a regulated process. Proc. Natl. Acad. Sci. USA. 88:1726-1730.

50. Molloy, S.S., L. Thomas, J.K. VanSlyke, P.E. Stenberg, and G. Thomas. 1994. Intracellular trafficking and activation of the furin proprotein convertase: localization to the TGN and recycling from the cell surface. EMBO (Eur. Mol. Biol. Organ.) J. 13:18-33.

51. Takahashi, S., T. Nakagawa, T. Banno, T. Watanabe, K. Murakami, and K. Nakayama. 1995. Localization of furin to the trans-Golgi network and recycling from the cell surface involves Ser and Tyr residues within the cytoplasmic domain. J. Biol. Chem. 270:28397-28401.

52. Derynck, R., A.B. Roberts, M.E. Winkler, E. Y Chen, and D V Goed del. 1984. Human transforming growth factor- $\alpha$ : precursor structure and expression in E. coli. Cell. 38:287-297.

53. Hormi, K., J.-P. Onolfo, L. Gres, V. Lebraud, and T. Lehy. 1995. Developmental expression of transfoming growth factor- $\alpha$ in the upper digestive tract and pancreas of the rat. Regul. Pept. 55:67-77. 